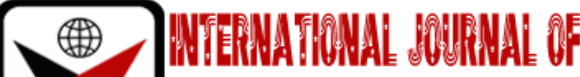

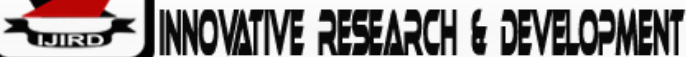

ISSN 2278-0211 (Online)

\section{The Influence of Person Organizational Fit and Person Job Fit on Performance Mediated by Innovative Work Behaviors of Employees of PT Pos Indonesia DC Plemburan Yogyakarta, Indonesia}

\author{
Anisa Dwi Anggraeni \\ Student, Department of Master Management, Indonesian Islamic University, Indonesia
}

\begin{abstract}
:
This study discusses the effect of person organization fit and person job fit on employee performance through innovative work behavior as mediation. The variables in this study are person organization fit, person job fit, innovative work behavior, and employee performance. This study uses a purposive sampling technique with the following criteria: permanent employees who work for at least 1 year. Respondents in this study amounted to 105 employees. The test tool used is SPSS version 25 with Path Analysis, and Sobel Test. The results of this study indicate that person organization fit and person job fit have a significant positive effect on innovative work behavior, innovative work behavior has a significant positive effect on employee performance.
\end{abstract}

Keywords: Person organization fit, person job fit, innovative work behavior, employee performance

\section{Introduction}

Organizations are no longer only required to have employees with above average abilities, but organizations must also have employees who are able to invest themselves to be fully involved in the workplace, proactive, and have a high commitment to quality performance standards (Bakker, 2011). Statement Bohlander and Snell (2010) stated that "Organizations face increasing challenges in terms of globalization, innovation, and technology and customer service".One company that requires employee performance to achieve high performance is PT Pos Indonesia (Persero). PT Pos Indonesia is one of the State-Owned Enterprises (BUMN) which is engaged in telecommunications services such as correspondence, demand deposits, money transfer/exchange and logistics services. PT Pos Indonesia strives to continuously improve its professionalism in communication services through directed and sustainable human resource development. PT Pos Indonesia has now been able to show its creativity in the development of the Indonesian postal sector by utilizing its network infrastructure. At present it can be said that Pos Indonesia is still one of the service companies with the largest distribution network in Indonesia. The number of post offices is more than 4,000 offices with distribution in 24,000 service points and has covered 100 percent of cities and regencies in Indonesia.

PT Pos Indonesia implements a customer-oriented business strategy and company operations. In adapting to the latest technological changes (technology transformation) that are taking place very quickly, such as the development of information technology that inevitably must be followed, the increasing demands for increased customer service and others, so that the readiness of human resources must continue to be improved as well. On this basis, PT Pos Indonesia employees are required to have the expertise and ability to think creatively and innovate and have the best ability to develop innovations to be able to achieve optimal employee performance. In addition, in order to increase the satisfaction of partners, clients, and customers to and feel the results of their hard work \& creativity. Innovative work behavior helps improve organizational performance (De Jong and Den Hartog, 2007, Farooqui, 2014).

\section{Literature Review and Hypotheses}

Kristof (1996) suggests that Person Organization Fit (PO Fit) can be interpreted in terms of concepts, namely 1. Value congruence, is the suitability between the individual's intrinsic values and the organization; 2. Congruence of goals (goal congruence), is the suitability between individual goals with the organization in this case is the leader and coworkers; 3 . The fulfillment of employee needs (employee need fulfillment) is a match between the needs of employees and the strengths contained in the work environment with the system and organizational structure; 4 . The suitability of culture-personality characteristics (culture personality congruence) is the suitability between the personality (nonvalues) of each individual and the climate or organizational culture.

According to Bohlander and Snell (2010), that individual job fit is a process of job specifications, in particular, help identify the individual competencies employees need for success-the knowledge, skills, abilities, and other factors (KSAOs) 
that leads to superior performance. In line with that, Cable and DeRue (2002) define person job fit as the suitability between individuals and the work or tasks they do in the workplace.

According to De Jong and Hartog (2008) define innovative work behavior as individual behavior that aims to reach the stage of introduction or trying to introduce (in work, groups or organizations) new ideas, processes, products or procedures useful. Innovative work behavior is defined as developing, adopting and implementing new product ideas, technologies and work methods. Innovation is not only related to generating new ideas but also providing an environment in which it can be achieved successfully (Yuan and Woodman, 2010).

Robbins and Judge (2017) state that employee performance is a combination of effectiveness and efficiency in carrying out the main tasks of employees. Employee performance is the ability to work or something achieved or achievement shown. Employee performance is an important indicator that reflects the work of individuals, departments, and organizations (Na-nan and Sanamthong, 2019).

\subsection{Effect of Person Organization Fit onInnovative Work Behavior}

In a study by Afsar et al., (2016), Wu and Ghao (2017) person organization fit is able to increase knowledge sharing behavior among employees. Research conducted by Wojtczuk-Turek and Turek (2016) shows that person organization fit can improve the creative and innovative work behavior.

Research conducted by Afsar and Badir (2017) indicates that person organization fit positively affects innovative work behavior.

- H1: Person organization fit has a positive effect on innovative work behavior.

\subsection{The Effect of Person Job Fit on Innovative Work Behavior}

Research conducted by Huang et al., (2019) indicated that employees who devote more time and energy because of their fit in work so that the creative process can more effectively identify problems, gather information, and propose solutions to challenges, so that employees come up with innovative ideas and apply them to their work (Afsar et al. al., 2016).

Research conducted by Suwanti et al., (2018) 134 employees were randomly selected from 200 employees of the banking sector in Indonesia. The results of this study found that person job fit is positively related to innovative work behavior. This study shows that person job fit plays an important role in influencing the innovative behavior of employees. Person job fit is an important factor in increasing organizational effectiveness. According to research by Afsar et al., (2015) PJ Fit has a positive effect on innovative work behavior. The results showed that more fit between employees and their jobs tends to increase innovative work behaviors that combine initiation with implementation of creative ideas.

Research conducted by Tang et al., (2021) on six hundred and ninety-seven employees from eight high-tech industries in China, high Person job fit can not only improve individual performance, but can also have different effects on long-term organizational outcomes. long, which closes the gap between the values, goals and characteristics of individuals and organizations, thereby increasing their compatibility and creating a harmonious organizational atmosphere that promotes organizational development.

The higher the person job fit in an organization, the higher the innovative work behavior. Conversely, the lower the person job fit, the lower the innovative work behavior.

- H2: Person job fit has a positive effect on innovative work behavior.

\subsection{Influence of Person Organization Fit on Employee Performance}

Research conducted by Farooqui and Nagendra (2014), Pramesti (2013) showed that there is a positive relationship between person organization fit and employee performance. Research conducted by Alfani (2018) showed that person organization fit has a significant effect on employee performance. If the perception of person organization fit on employee performance is applied well to employees, then this employee's performance will be even better or fit. Research conducted by Maria and Ahyar (2016) according to this study if the company's goals are in accordance with the goals of the employee's work, it can provide opportunities for employees to achieve their personal goals.

Research conducted by Wei (2015) uses survey data collected from 456 engineers and their direct supervisors in 31 high-tech Taiwanese companies. This study also shows that person organization fit is positively related to the practice of human resource performance. Companies must ensure employees are a good fit for their organization to reduce the negative impact of losing talent on the organization that will affect employee performance.

If the level of conformity between employees and the organization is high, it will show greater results or higher performance.

- H3: Person organization fit has a positive effect on employee performance

\subsection{The Influence of Person Job Fit on Employee Performance}

Research conducted by Astakhova and Porter (2015) uses data from 233 employees and supervisors from several organizations in Russia. This study shows that when job compatibility is high, employees will improve the quality of their work, because they feel confident that their efforts will bring the desired results in the form of organizational rewards.

Research conducted by June and Rosli (2011) to examine the relationship between person job fit and employee performance in the service sector of small and medium enterprises (SMEs). This study uses 300 employee surveys to be the unit of analysis for this study. The results of the study indicate that there is a significant relationship between personjob fit and employee performance, when employees are matched with the work they do, they tend to put more effort into carrying out their duties, thereby increasing work performance. 
Research conducted by Pudjiarti and Prihatin (2020), June et.al (2013) showed that person job fit has a positive effect on employee performance. Research conducted by Gul et al., (2018) proved that person job fit has a direct effect on employee performance. In this study it is explained that employees cannot work well if they are not equipped with the right types of skills and abilities, knowledge in accordance with the demands of their work.

If the suitability between the employee's abilities and the demands of the job is high, it will result in high employee work performance.

- H4: Person Job Fit has a positive effect on Employee Performance

\subsection{Influence of Innovative Work Behavior on Employee Performance}

Research conducted by Leong and Rasli (2014) proved that the innovative work behavior of employees is positively related to employee performance. Research conducted by Pudjiarti and Prihatin (2020) showed that the variable of innovative work behavior has a positive effect on employee performance. Research conducted by Kim and Dong (2017) on hotel employees in South Korea. This study shows that innovative work behavior has a significant effect on employee performance. In other words, the higher the innovative work behavior, the higher the performance of an individual.

Research conducted by Nasir et al., (2018) This research was conducted on the teaching staff of Syiah Kuala University with 230 questionnaires using SEM analysis and the results showed that employee performance was significantly influenced by innovative work behavior.

H5: Innovative Work Behavior has a positive effect on Employee Performance

\subsection{Innovative Work Behavior as Mediation}

Research on the relationship between innovative work behavior and performance was also conducted by Jiménez \&Sanz (2011), Tims et al., (2016). Pudjiarti and Prihatin (2020) stated that innovative work behavior is being measured by the success of organizational members. If employees have appropriate organizational values and work compatibility that are in line with their organization, employees will bring up innovative behavior or new ideas in completing work well because employees feel that they have a great responsibility for their work.

- H6: Innovative Work Behavior mediates the influence of Person Organization Fit on Employee Performance

- H7: Innovative Work Behavior mediates the influence of Person Job Fit on Employee Performance

\section{Research Methods}

This study uses a descriptive quantitative approach. With a population of 105 employees of PT Pos Indonesia DC Plemburan Yogyakarta, using a random sampling technique with the criteria: permanent employees and have worked for at least 1 year so that the respondents in this sample amounted to 105 employees collecting data using a questionnaire. The analytical tool in this study used SPPS 25.

\subsection{Person Organization Fit}

Person-organization fit is defined as a perceived fit between employees and the organization starting from the vision and mission, values, goals, and culture. Measurement of person-organization fit using indicators from Kristof (1996), namely: suitability, Conformity, Conformity, Suitability, Conformity.

\subsection{Person Job Fit}

Person-Job fit is defined operationally as the employee's perception of the suitability of the employee's personality with the job demands of the organization. Measurement of person job fit uses indicators adapted from Cable and Derue (2002) and is a form of development from Lauver and Kristof-Brown (2001), namely:

- The degree of congruence between the job the employee expects and what is offered

- The level of suitability of employee attributes in the workplace is in accordance with the work being carried out at this time

- The level of suitability of the interests and hobbies of employees with the work they do

- The level of suitability of the employee's abilities/skills with the work performed

- Degree of congruence between job demands and personal skills

- The degree of correspondence between the training offered by the job and the needs

- The level of compatibility between the abilities possessed by employees from education and experience with the demands of the job currently held.

\subsection{Innovative Work Behavior}

Innovative work behavior is defined operationally as the behavior of employees who are able to provide or spark new creative ideas. The measurement indicators of innovative work behavior used according to De Jong and Den Hartog (2010), namely:

- $\quad$ Finding new work methods, techniques or instruments

- Get new ideas/ideas from experience

- Creating solutions to problems or opportunities

- communicating new ideas/ideas to superiors

- $\quad$ The desire to be different from others 
- Ability to exert influence in mobilizing available support and resources so that ideas can be realized.

- Trying to get support from colleagues regarding the ideas that you get

- $\quad$ Trying to get approval for the ideas / ideas that are obtained

- Trying to realize new ideas/ideas into applications/programs

- Ability to make suggestions to improve product or service processes

\subsection{Employee Performance}

According to Edison et al., (2017) performance is the result of a process that refers and is measured over a certain period of time based on pre-determined provisions and agreements. Employee performance appraisal is carried out by the direct supervisor. Meanwhile, the measurement of employee performance uses the indicators proposed by Gomes (2003):

- Quantity of work (Achievement of targets in terms of quantity)

- Quality of work (Achievement of the target from the aspect of quality)

- Knowledge (level of understanding of the task being done)

- Creativity (Giving creative ideas)

- Cooperation (willingness to cooperate with others, for exampleAgencies, superiors and co-workers)

- $\quad$ Responsibility (responsibility in doing work)

\section{Result}

\subsection{Descriptive Analysis}

Descriptive data that describe the condition or condition of the respondent need to be considered as additional information to understand the results of the study. Based on the results of respondents' answers regarding gender, age, years of service and the last education of respondents, it can be concluded that the majority of PT Pos Indonesia DC Plemburan Yogyakarta employees are male, namely 95 employees or 91.3\% and female respondents are 9 employees or 8 , $7 \%$. The majority are between $26-35$ years old, which is $48.1 \%$. Meanwhile, the other age distributions are those between 36 - 45 years old by $36.5 \%$, and between 46 - 55 years old by $15.4 \%$. Graduated Bachelor (S1) as many as 28 employees or $26.9 \%$, while Diploma (D3) were 7 employees or $6.7 \%$ and the last education was high school/equivalent by 69 people or $66.3 \%$

\subsection{Inferential Analysis}

\subsubsection{Test Validity}

Validity test is used to measure the validity of a questionnaire by using a significance level of 0.05 (5\%).

\subsubsection{Reliability Test}

Reliability Test is used to obtain reliable results by using spssCronbach alpha $>0.6$.

\subsubsection{Normality Test}

The results of the Normality Test showed a significant value of the Kolmogorov Smirnov Normality Test results of 0.469. Due to the significant value of the normality test results $>0.05$, it is concluded that all data in this research variable are normally distributed.

\subsubsection{Multicollinearity Test}

The multicollinearity test results show that all independent variables have a Variance Inflation Factor (VIF) value less than 10, thus all independent variables in this study have no multicollinearity.

\subsubsection{Heteroscedasticity Test}

Heteroscedasticity test used the glejser test between the scores of each independent variable and the absolute value of the residual. The test results show that the $\mathrm{p}$-value for all variables is greater than 0.05 , so it can be concluded that all variables in this study have no heteroscedasticity.

\section{Path Analysis}

Path analysis is a regression model used to test the correlation of two or more variables in the model (Ghozali, 2011). The influence of analysis can be described as follows: 


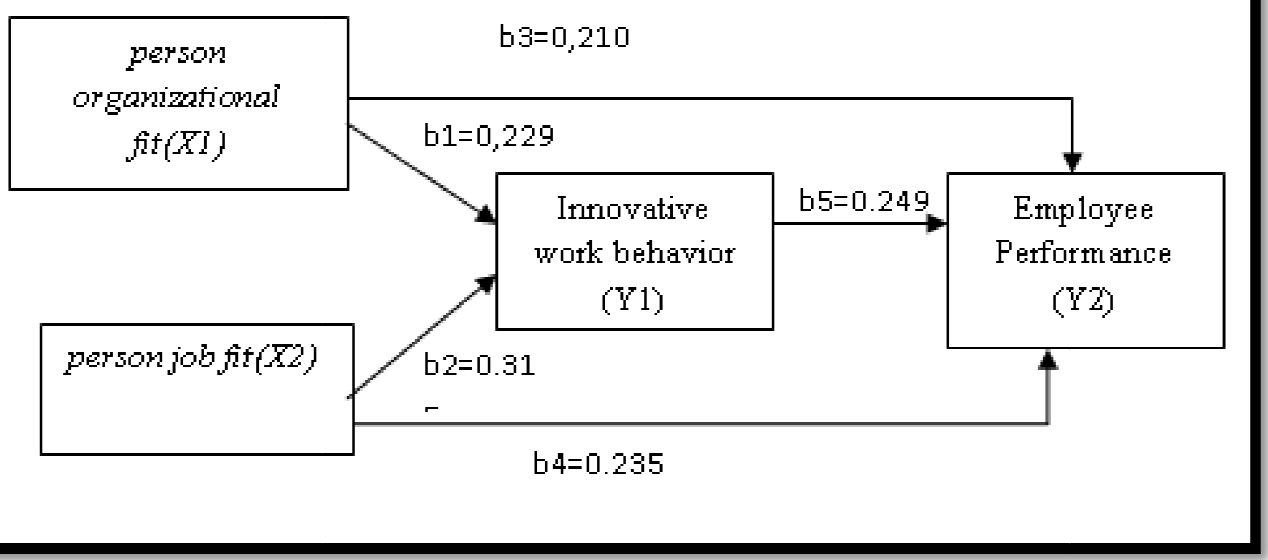

Figure 1

Based on the diagram above, it can be made a summary of the results with the following details: Mediation hypothesis testing is calculated using a procedure developed by Sobel (Ghozali, 2016).

\begin{tabular}{|c|c|c|c|}
\hline Influence Model & Direct Effect & Indirect Effect & Total Effect \\
\hline $\mathrm{X} 1 \rightarrow \mathrm{Y} 1$ & 0.229 & - & - \\
\hline $\mathrm{X} 2 \rightarrow \mathrm{Y} 1$ & 0.315 & - & - \\
\hline $\mathrm{X} 1 \rightarrow \mathrm{Y} 2$ & 0.210 & - & - \\
\hline $\mathrm{X} 2 \rightarrow \mathrm{Y} 2$ & 0.235 & - & - \\
\hline $\mathrm{Y} 1 \rightarrow \mathrm{Y} 2$ & 0.249 & - & - \\
\hline $\mathrm{X} 1 \rightarrow \mathrm{Y} 1 \rightarrow \mathrm{Y} 2$ & & 0.057 & 0.267 \\
\hline $\mathrm{X} 2 \rightarrow \mathrm{Y} 1 \rightarrow \mathrm{Y} 2$ & & 0.078 & 0.380 \\
\hline
\end{tabular}

Table 1: Result Test

\subsection{Testing Mediation Effects 2}

$$
\mathrm{t}=2.441
$$

$$
t=\frac{0,299 \times 0,249}{\sqrt{0,249^{2} 0,083^{2}+0,299^{2} 0,075^{2}+0,083^{2} 0,075^{2}}}
$$

From the calculation of sobel test above, obtained $\mathrm{Z}$ value of 2.441 , because $2.441>1.66256$ with a significance of 0.05 , it proves that innovative work behavior is able to mediate the effect of person organization fit on employee performance.

\subsection{Testing Mediation Effects 2}

$$
t=\frac{0,315 \times 0,249}{\sqrt{0,249^{2} 0,136^{2}+0,315^{2} 0,075^{2}+0,136^{2} 0,075^{2}}}
$$

$\mathrm{t}=1.909$

From the calculation of sobel test above, obtained $\mathrm{Z}$ value of 1.909 , because $1.909>1.66256$ with a significance of 0.05 , it proves that innovative work behavior is able to mediate the effect of person job fit on employee performance.

\section{Discussion}

\subsection{Person Organization Fit on Innovative work behavior}

Research by Afsar et.al (2015) showing employee perceptions of person organization fit positively affect employee innovative work behavior. Person organization fit can help employees build long-term relationships with the organization, and they are likely to exhibit behaviors that have a positive impact on organizational achievement.

Companies should be able to develop employees' innovative work behavior by selecting and retaining individuals who are more in line with the organization's values and culture. When employees show a positive evaluation of perceived fit, they will see that their skills and knowledge enable them to manage certain tasks, which is a source of satisfaction and a factor that can lead to employee innovation.

\subsection{Person Job Fit on Innovative Work Behavior}

The results showed that there was a positive and significant influence between Person Job Fit on innovative work behavior. This means that the higher the person job fit, the innovative work behavior of employees will increase. The results of this study are in accordance with the results of research by Suwanti et al., (2018) that person job fit is positively related to the innovative work behavior of employees in the banking sector in Indonesia. Person job fit refers to the match between employee abilities and job demands. Employees are more likely to perceive work when they have personal values that align with work values. 
Employees will give more time and energy because there is a fit in the work so that the creative process can more effectively identify problems, gather information, and propose solutions to challenges. (Huang et al., 2019). Innovative work behavior has an important role in customer satisfaction in business. Employees who work in jobs that match the job description are very important, in order to provide more innovative and quality services.

\subsection{Person Organization Fit on Employee Performance}

Alfani's research (2018), Farooqui and Nagendra (2014) showed that person organization fit has a significant effect on employee performance at the Islamic University of Kalimantan Muhammad Arsyad Al Banjari, Banjarmasin. Employees will be happy to work in an organization, where they feel that the values of the organization are in line with their own values, and the organization will recruit employees whose values are in line with the values of the organization. According to his abilities, he will work satisfactorily and show greater results or higher performance. The company's management should ensure that employees match the organization where they work, this is to reduce the negative impact of moving talented employees to other companies, so that it will affect employee performance. In addition, companies must build a human resource system that can attract and retain employees who excel or have high performance.

\subsection{Job Fit on Employee Performance}

Gul et.al (2018) is showing a significant positive relationship between person job fit and employee performance. Employees tend to like work that is meaningful and can fulfill their internal and external needs, because when person job fit occurs, employees tend to perform better at work and they are willing to spend their energy to complete tasks that they enjoy. Therefore, when there is a good match between employees and jobs, employees will be able to strive to perform better in improving their performance.

\subsection{Innovative Work Behavior on Employee Performance}

The results showed that there was a positive and significant influence between innovative work behavior on employee performance. This means that the higher the innovative work behavior, the employee's performance will increase. The results of this study are in accordance with the research Leong and Rasli (2014) shows that innovative work behavior has a significant relationship to employee performance in an integrated automotive organization based in Malaysia. The role of innovative behavior can accelerate the mindset of individuals and in turn improve performance. As is the case when employees use their skills and knowledge to manage certain tasks with their creativity and innovation in completing their tasks, so that they can work effectively, this becomes a source to improve their performance.

Innovative work behavior requires employees to behave proactively in the form of personal initiatives and new ideas that are directly related to company performance. New ideas include initiating innovation in the form of new products and services, or by proposing improvements to existing procedures or processes and finding efficient and effective alternative solutions to perform tasks. These ideas can make it possible to improve employee performance.

\subsection{Person Organization Fit on Employee Performance Through Innovative Work Behavior}

The results of the Sobel test analysis show that person organization fit has a significant effect on employee performance through innovative work behavior. The results of this study are in accordance with the research of Afsar et al., (2015). Therefore, it is important for organizations to provide resources and an environment that supports the creation of new innovations, appreciate the results of employee innovation, create relationships and reciprocal communication between the organization and employees, and provide information about the latest trends so that employees can innovate effectively.

\subsection{Person Job Fit on Employee Performance through Innovative Work Behavior}

The results of the Sobel test analysis show that Person Job Fit has a significant effect on employee performance through innovative work behavior with a t value of 1.909. When the employee's personality and work are in line, employee performance will increase by itself. In this case someone will understand the meaning of his work so that he can have the opportunity to develop himself in the world of work and employees will try to create new innovations that support career development and performance.

The match between employee abilities and work tends to increase innovative work behavior, so that new innovations emerge with the implementation of creative ideas. Employees who work in accordance with their knowledge, talents and abilities will contribute more in developing new methods and techniques that are more creative, so as to improve performance.

\section{References}

i. Afsar, B., Badir, Y., Khan, M.M. (2016). The mediating role of psychological empowerment on the relationship between person-organization fit and innovative work behaviour. Journal of Chinese Human Resource Management, 7(1), 5-26.

ii. Afsar, B., Badir, Y. (2017). Workplace spirituality, perceived organization support and innovative work behavior: The mediating effects of person-organization fit. Journal of Workplace Learning, 29(2), 95-109.

iii. Alfani, Muhammad \& Muhammad Hadini. (2018). Pengaruh Person Job Fit dan Person Organization Fit Terhadap Organizational Citizenship Behavior danKinerjaKaryawanUniversitas Islam Kalimantan Muhammad Arsyad Al Banjari Banjarmasin. JurnalRisetInspirasiManajemen Dan Kewirausahaan, 2 (2), 73-85. 
iv. Astakhova, M.N., Porter, G. (2015). Understanding the work passion-performance relationship: The mediating role of organizational identification and mode rating role of fit at work. Human Relations, 7, 1-32.

v. Bakker, Arnold B., Simon L., Michael P. (2011). Key Questions Regarding Work Engagement. European Journal of Work and Organizational Psychology. Psychology Press.

vi. Bohlander, George., and Snell, Scott, 2010. Principles of Human Resource Management, 15th ed. Mason, 0H: South Western - Cengage Learning. Cable, D. M., \&Derue, D. S. (2002). The convergent and discriminant validity of subjective fit perceptions. Journal of Applied Psychology, 87(5), 875-884.

vii. De Jong, J. P., \& Den Hartog, D. N. (2008). Innovative work behavior: Measurement and validation. EIM Business and Policy Research, 8(1), 1-27.

viii. De Jong, J., \& den Hartog, D. (2010). Measuring Innovative Work Behaviour. Creativity and Innovation Management, Blackwell Publishing Ltd, 19(1), 23-36. doi:10.1111/j.1467-8691.2010.00547.x

ix. De Jong, J.P.J. and den Hartog, D.N. (2007): How Leaders Influence Employees "Innovative Behaviour, European Journal of Innovation Management, 10 (1), 41-64.

x. Edison, E., Anwar, Y., Komariyah, I. (2017). ManajemenSumberDayaManusia. Bandung, Alfabeta.

xi. Farooqui, M. S., \&Nagendra, A. (2014). The Impact of Person Organization Fit on Job Satisfaction and Performance of the Employees. Procedia Economics and Finance, 11, 122-129. doi:10.1016/s22125671(14)00182-8

xii. Ghozali, I. (2011). AplikasiAnalisis Multivariate Dangan Program IBM SPSS 19. Semarang: Badan Penerbit UniversitasDiponegoro

xiii. (2016). AplikasiAnalisisMultivarietedengan Program IBM SPSS 23 (Edisi 8) Cetakanke VIII. Semarang: Badan Penerbit UniversitasDiponegoro.

xiv. Gomes, Faustino Cardoso. (2003). ManajemenSumberDayaManusia.Yogyakarta: Andi Offset.

xv. Gul, H., Usman, M., Liu, Y., Rehman, Z., \&Jebran, K. (2018). Does the effect of power distance moderate the relation between person environment fit and job satisfaction leading to job performance? Evidence from Afghanistan and Pakistan. Future Business Journal, 4(1), 68-83.

xvi. Huang, W., Yuan, C., \& Li, M. (2019). Person-Job Fit and Innovation Behavior: Roles of Job Involvement and Career Commitment. Frontiers in Psychology, 10. doi:10.3389/fpsyg.2019.01134

xvii. Jiménez-Jiménez, D., \&Sanz-Valle, R. (2011). Innovation, organizational learning, and performance. Journal of Business Research, 64(4), 408-417. doi:10.1016/j.jbusres.2010.09.010.

xviii. June, S., \& Mahmood, R. (2011). The relationship between person-job fit and job performance: A study among the employees of the service sector SMEs in Malaysia. International Journal of Business, Humanities and Technology, 1(2), 95-105.

xix. June, S., Yeoh, K. K., \& Mahmood, R. (2013). Determining the importance of competency and person-job fit for the job performance of service SMEs employees in Malaysia. Asian Social Science, 9(10), 114-123.

xx. Kim, M.-S. and Dong Woo Koo. (2017), Linking LMX, engagement, innovative behavior, and job performance in hotel employee. International Journal of Contemporary Hospitality Management, 29 (12), 3044-3062.

xxi. Kristof, A.L. (1996), Person-Organization Fit : An integrative review of its concepttualizations, measurement and implications. Personnel Psychology, 49: 1-49.

xxii. Lauver, K. J., \&Kristof-Brown, A. (2001). Distinguishing between Employees' Perceptions of Person-Job and Person-Organization Fit. Journal of Vocational Behavior, 59(3), 454-470. doi:10.1006/jvbe.2001.1807.

xxiii. Leong, C. T., \&Rasli, A. (2014). The Relationship between innovative work behavior on work role performance: An empirical study. Procedia-Social and Behavioral Sciences, 129, 592-600.

xxiv. Maria, Helena Stefani \&AhyarYuniawan. (2016). AnalisisPengaruh Person- Organization Fit TerhadapKinerjaKaryawan: KomitmenOrganisasional Dan Organizational Citizenship Behaviour SebagaiVariabelIntervening :StudiPadaKaryawan Pt Telkom WitelPekalongan. Diponegoro Journal of Management, 5(1),1-15.

xxv. Na-nan, K., \&Sanamthong, E. (2019). Self-efficacy and employee job performance Mediating effects of perceived workplace support, motivation to transfer and transfer of training. International Journal of Quality \& Reliability Management, 37(1), 1-17.

xxvi. Nasir, Halimatussakdiah et al., (2018). How Intrinsic Motivation and Innovative Work Behavior Affect Job Performance. Advances in Social Science, Education and Humanities Research. Atlantis Press, 292, 606-612.

xxvii. Pramesti, AnnurIntan. (2013). Pengaruh Person Organization terhadapMotivasidanKinerjaKaryawanpadaKaryawan PT. Bank Pembangunan Daerah JawaTimur (Bank Jatim) CabangLamongan. JurnalAdministrasiPerkantoran (JPAP), 1(1).

xxviii. Pudjiarti, Emiliana\&PrihatinTiyanto. (2020). Innovative work behaviour: An integrative investigation of person-job fit, person-organization fit, and person-group fit. Business: Theory and Practice, 21,39-47.

xxix. Robbins, S.P., \& Judge, T.A. (2017). Organizational Behaviour, 17th Edition. New Jersey: Pearson

xxx. Suwanti, S. \& U. Udin\& W. Widodo, (2018). Person-Organization Fit, Person-Job Fit, and Innovative Work Behavior: The Role of Organizational Citizenship Behavior. International Journal of Economics \& Business Administration (IJEBA), 0(3), pages 146-159.

xxxi. Tang, Yuan et al., (2021). How to Keep Sustainable Development Between Enterprises and Employees? Evaluating the Impact of Person-Organization Fit and Person-Job Fit on Innovative Behavior, Front. Psychol,12, 1-13. 
xxxii. Tims, M., Derks, D., \& Bakker, A. B. (2016). Job crafting and its relationships with person-job fit and meaningfulness: A three-wave study. Journal of Vocational Behavior, 92, 44-53.

xxxiii. Wei, Y. C. (2015). Do employees high in general human capital tend to have higher turnover intention? The moderating role of high-performance HR practices and P-O fit. Personnel Review, 44(5), 739-756.

xxxiv. Wojtczuk-Turek, A., Turek, D. (2016). The significance of perceived social-organization climate for creating employees' innovativeness - The mediating role of person organization fit. Management Research Review, 39(2), 167-195.

xxxv. Wu, Chen \&Gao Wu. (2017). Person-organization fit relationship with innovative performance of employees: A literature review. Advances in Social Science, Education and Humanities Research (ASSEHR), Atlantis Press, 80, 185-189.

xxxvi. Yuan, F., \& Woodman, R.W. (2010). Innovative behaviour in the workplace: The role of performance and image outcome expectations. Academy of Management Journal, 53(2), 323-342. 